\title{
Can the resource curse be avoided? An empirical examination of the nexus between crude oil price and economic growth
}

\author{
Clovis Wendji Miamo ${ }^{1}$ - Elvis Dze Achuo ${ }^{1,2}$
}

Received: 20 July 2021 / Accepted: 10 November 2021 / Published online: 20 December 2021

(c) The Author(s), under exclusive licence to Springer Nature Switzerland AG 2021

\begin{abstract}
This paper revisits the resource curse hypothesis by examining the nexus between crude oil price and economic growth for a panel of 32 Sub-Saharan Africa countries from 1980 to 2017. Employing the panel vector autoregression (VAR) estimation technique, we found evidence of a significant positive effect of crude oil price on economic growth both in the short run and long run. However, after splitting the panel into net oil exporters and importers, the results for net oil importers remain consistent with those obtained for the whole panel, unlike those for net oil exporters revealing a positive and negative effect of crude oil price on economic growth in the short-run and long-run periods, respectively. This confirms the resource curse hypothesis for oil-exporting countries under consideration. Moreover, we found evidence of bidirectional causality between crude oil price and real GDP. Consequently, to boost economic growth in Sub-Saharan Africa, various governments should encourage economic diversification, increase investments in human capital in view of enhancing the development of the oil sector by ensuring an efficient management of oil revenues, as well as intensifying the fight against corruption.
\end{abstract}

Keywords Crude oil price $\cdot$ Economic growth $\cdot$ Resource curse $\cdot$ Panel VAR

JEL Classification Q31 · F43 - Q32 · C13

Elvis Dze Achuo

elratina@ymail.com

Clovis Wendji Miamo

c_miamo_w@yahoo.fr

1 University of Dschang, Dschang, Cameroon

2 Ministry of Secondary Education (MINESEC), Yaoundé, Cameroon 


\section{Introduction}

Understanding why some resource-poor countries outperform their resource-rich counterparts has been a major preoccupation to researchers as well as policymakers. Hence, over the last 3 decades, the hypothesis that natural resource endowments are an impellent to a country's development has remained a contemporary debate topic among researchers in the field of development economics. Thus, the question whether resource wealth is a blessing or curse to socioeconomic development remains ambiguous. While the development of some countries is believed to have been propelled by their natural resource endowments (Deaton 1999), the underdevelopment of others, especially Sub-Saharan Africa (SSA) resource-rich countries has been blamed on their overdependence on natural resource exploitation (Sachs and Warner 1995). This counterintuitive development outcome has led to what has been baptised by oil researchers as the "natural resource curse", born sequel to the seminal work of Auty (1993). Motivated by the controversies in economic literature regarding the effect of natural resource endowments on the socio-politico-economic development of countries across the globe, this paper revisits the resource curse hypothesis by examining the long-run and dynamic causal nexus between crude oil price and economic growth in SSA.

The present-day socioeconomic upheavals confronted by world economies are symptoms of a profounder malady without any proven remedy. Furthermore, these growth challenges faced by countries across the globe, especially engendered by the novel coronavirus pandemic seem to curtail the global possibility of achieving the sustainable development goals outlined in the global development agenda (United Nations 2015). Whence, while the global economy was projected to witness a decline in growth of about - 3\% in 2020 down from $2.4 \%$ in 2019 , that of the Euro zone was expected to fall from $1.2 \%$ in 2019 to $-7.5 \%$ in 2020 . Equally, Sub-Saharan Africa (SSA) growth has been dwindling over the years, falling from 2.7 to $2.4 \%$ between 2017 and 2019 . Hence, following the sharp fall in oil prices in the first quarter of 2020 by about $50 \%$ from its 2019 level, it was projected that this growth could further worsen and plummet to its lowest ever level of about $-1.6 \%$ by the end of 2020 (IMF 2020; Achuo et al. 2020; Steinbach and Sandhu 2020). Nevertheless, economic growth literature opines that oil price shocks are major exogenous drivers of macroeconomic variability.

Howbeit, recent trends in oil prices and growth rates across the globe have reawakened debates on the nexus between crude oil price and economic growth. On the one hand, several oil studies before the early 2000s considered oil as a magic lever to growth. For instance, according to the 2015 Economics Nobel laureate, Deaton (1999), oil price hikes have positive effects on Africa's economic development. However, this view remains questionable as some researchers consider natural resource wealth as speed brakes to the socioeconomic development of Africa (Carmignani and Avom 2010). Likewise, some oil exporters who, theoretically are supposed to be positively impacted during periods of oil price hikes often face worse economic meltdowns than their net oil-importing counterparts; thus, confirming the resource curse hypothesis (Auty 1993; Sachs and Warner 1995). 
Brent Crude Oil Price $\quad$ Growth Rate

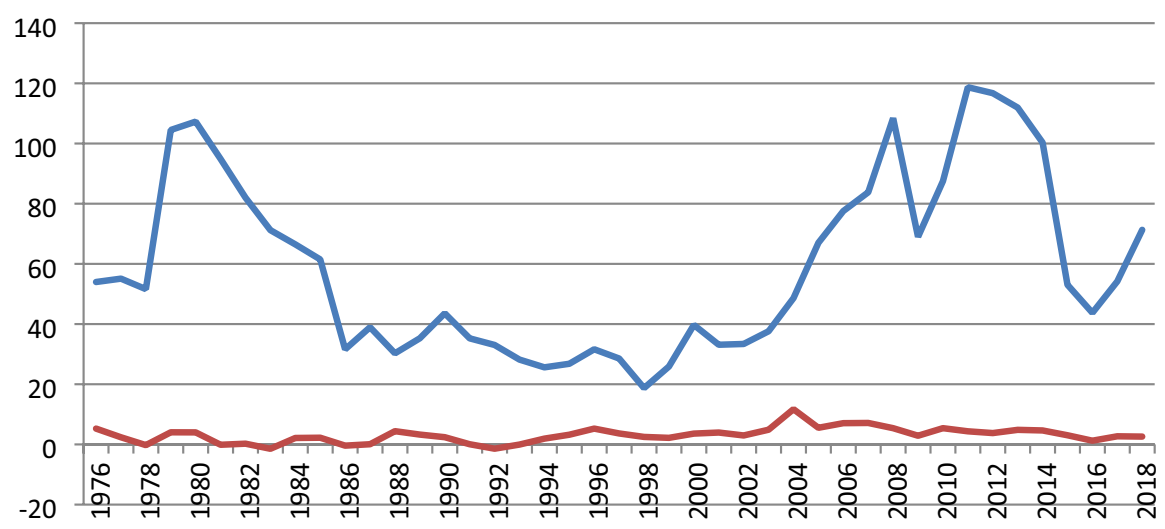

Fig. 1 Evolution of crude oil price and GDP growth in SSA

Whence, the degree of correlation between economic growth and oil prices is believed to be very high in countries with high natural resources dependence. Consequently, a glance at growth and oil data from 1976 to 2018 (see Fig. 1 below) reveals that SSA has witnessed great variations in its growth rate with highest and lowest values of $11.7 \%$ and $-1.45 \%$ recorded in 2004 and 1983, respectively. These variations have, however, been consistent with respective oil price surges. Withal, the growth trend between 2016 and 2018 is positive following a similar positive trend of oil prices.

Moreover, the recurrent oil price variations with its inherent socioeconomic consequences remain a major preoccupation not only to researchers, but also to policy makers and development agencies around the world. Recently, Miamo and Achuo (2021) established a positive link between crude oil price and economic growth, which is consistent with the trend observed in Fig. 1. However, it is intuitively believed that respective oil price increases and decreases are likely to be beneficial and detrimental to resource-rich net oil-exporting countries, unlike their resourcepoor counterparts who are likely to benefit from oil price decreases. Nevertheless, the results of several studies have been counterintuitive (Auty 2001; Sachs and Warner 1997), thereby leading to the validation of the resource curse hypothesis.

Although a host of studies have investigated the nexus between crude oil price shocks and economic growth, most of such studies have predominantly focused on developed economies. Besides, the few existing studies for SSA often employ time series analysis with smattering panel studies available. In addition, to the best of our knowledge, previous studies in SSA have either considered the oil-GDP growth nexus for a group of net oil exporters or importers. We, thus, contribute to this area of study by taking into consideration both net oil importers and exporters and looking at the combined effects, before splitting the panel into net oil exporters and importers to check for robustness of our results with regard to earlier empirical findings and theoretical foundations. This paper is, thus, imperative to fill this gap. 
Consequently, the purpose of this paper is twofold: (i) to revisit the resource curse hypothesis by examining the effect of crude oil price changes on economic growth, (ii) to investigate whether there exist long-run causality between crude oil price and economic growth.

To achieve these objectives, this study employs the novel panel vector autoregression (PVAR) estimation technique proposed by Abrigo and Love (2016) as well as the Toda-Yamamoto (1995) causality test for a panel of 32 SSA countries from 1980 to 2017. Our results confirmed earlier findings by Deaton (1999) by showing that crude oil price has a significant positive effect on economic growth both in the short- and long-run periods. These results remain consistent with the employment of other robust estimation techniques. Unsurprisingly, after splitting the panel into net oil exporters and importers, the results for net oil exporters reveal a positive and negative effect of crude oil price on economic growth in the short- and long-run periods, respectively, thereby validating the resource curse hypothesis in the context of oil-exporting SSA countries. Moreover, we found evidence of bidirectional causality between crude oil price and real GDP.

Following the introduction, the remainder of this paper is outlined as follows: section two reviews the relevant literature, section three outlines the empirical methodology, section four presents and discusses the empirical findings, while the concluding remarks are contained in section five.

\section{Brief review of theoretical and empirical literature}

This section X-rays pertinent theoretical and empirical underpinnings with regard to the nexus between crude oil price changes and economic growth. In this light we first explore some classical theories notably the Solow (1956) Model and the Kydland-Prescott (1982) Real Business Cycle (RBC) theory, as well as conventional growth theories. The Solow growth model propounded by Robert Solow, the 1987 Economics Nobel prize laureate is based on the premise that output depends on labour and capital, assuming constant returns to scale. Despite the numerous refinements undergone by the Solow model, it remains very vital for modern growth studies. Thus, Mankiw (1995) contends that the neoclassical growth model should be the starting point of discussions by economists with regard to long-run growth. Equally, the RBC theory, developed in 1982 by the 2004 Economics Nobel prize laureates, Kydland and Prescott considers that economic crisis and fluctuations are caused by external shocks stemming from resource and technology constraints (Stadler 1994). The incorporation of energy prices into various extensions of the RBC theory is therefore of prime importance in the context of this study.

Besides the classical growth theories, this paper is inspired by four conventional theories which hypothesise that economic growth is driven by crude oil price changes. First, Samuelson and Nordhaus (1985) in the mainstream theory of economic growth contend that economic growth is determined principally by production which in turn depends on energy. Moreover, the theory assumes that production is made possible by primary factors (capital, labour and land) and intermediate factors (notably fuel, coal, oil and gas). Secondly, the Linear/symmetric relationship 
growth theory advocated by Hamilton (1983) and Hooker (1986) hypothesizes the existence of a significant negative relation between oil price hikes and GDP growth. Furthermore, Herrera et al. (2015) opine that the direct-supply effect of an increase in crude oil price is symmetric although its sign is ambiguous for oil-exporting countries depending on the size of the oil sector to the country's GDP. Thirdly, the asymmetry theory of economic growth, whose hypothesis were confirmed for African economies by Mark et al. (1994) underscores the existence of a negative and ambiguous effect on future GDP growth following respective increases and decreases in oil price. Lastly, the nexus between crude oil price and growth is acknowledged by the renaissance growth theory wherein Lee and Ratti (1995) differentiate between oil price volatility and oil price changes. While the effect of the latter on economic growth is felt after a one year lag, that of the former is immediate.

Nevertheless, irrespective of the variants observed in the preceding theories, we notice a common point of concordance among the proponents, which is the existence of a relationship between crude oil price changes and economic growth. Hence, there is need to empirically examine the effect of crude oil price changes on economic growth. Therefore, having highlighted the theoretical basis for the oil price and real GDP nexus, we now explore some salient empirical studies within and without SSA countries.

On the one hand, a survey of studies across the world outside SSA have provided conflicting results with respect to the oil price and economic growth nexus. For instance, Samimi and Shahryar (2009) employ the Structural VAR model on annual data for six OPEC member states (Saudi Arabia, Iran, Kuwait, Nigeria, Venezuela and Indonesia) and found a positive long run effect of oil shocks on the real GDP for all countries, except Kuwait where the impact was, respectively, positive and negative in the short and long run. Conversely, Qazi (2013) adopting a similar modelling framework on the same countries found varying effects for different countries. The author opines that while the effect of an oil shock on GDP growth was significantly negative for Algeria, it was significantly positive for Venezuela. However, the results were statistically insignificant for the rest of the countries.

Similarly, Berument et al. (2010) employed the VAR model for the Middle East and North Africa (MENA) zone and varying results were found for net oil exporters and importers. While they found a significant positive effect of oil price increases on output growth for net oil exporters, the effect was insignificant on the output growth of net oil importers. Similar results have been reported for net oil exporters like Venezuela (Mendoza and Vera 2010) and Azerbaijan (Mukhtarov et al. 2020). Conversely, Ftiti et al. (2016) opine that this relation is negative in a study conducted on four OPEC countries, a result consonant to the findings of a study for the ASEAN-5 countries by Aziz and Dahalan (2015).

Parallelly, Yoshino and Taghizadeh-Hesary (2014) investigate the impact of crude oil price fluctuations on GDP growth rate and inflation in China, Japan and the United States (US) and assert that while an oil price increase negatively impacts Chinese GDP growth, the effect is positive on the GDP growth of Japan and the US. Hence, they conclude that the impact of oil price changes on the GDP growth rate are much slower for developed net oil-importing economies like the US and Japan than on an emerging economy like China. Similar results 
have been reported for China (Khan et al. 2017) and India (EXIM Bank 2018). However, these findings for net oil importers contradict the findings of Chen et al. (2015) who posit that oil price positively impacts the economic growth of the Chinese economy.

On the other hand, cross-country studies focused on net oil-exporting SSA countries in particular have found evidence of the resource curse. For instance, Besso and Pamen (2017) employing a panel VAR modelling framework for 6 countries of the Economic Community of Central African States (CEMAC) concluded that oil price has a significant negative long-run effect on real GDP growth. Although this result disagrees with the findings of Omolade et al. (2019), it is consistent with the findings of Omojolaibi and Egwaikhide (2013) and Akanni (2007). Besides, unlike Deaton (1999) and Nchofoung et al. (2021) who found a positive nexus between natural resource wealth and socioeconomic development, a number of studies have concluded that natural resource exploitation constitutes a major hindrance to the socioeconomic development of African countries (Carmignani and Avom 2010; Sachs and Warner 1995).

In addition, Sachs and Warner (1997) contend that dismal openness to foreign trade and poor economic policies have greatly slowed Africa's development. Low trade openness further worsens a country's ability to attract substantial foreign direct investments (FDI), likely to enhance a country's economic growth. Nevertheless, a positive nexus has been established between crude oil price and various growth indicators at the individual country level notably for Cameroon (Miamo and Achuo 2021; Forgha et al. 2015) and Nigeria (Mesagan et al. 2018; Ogboru et al. 2017; Oriakhi and Osaze 2013). The apparent conflicting results may, however, result from the different methodologies and variables included in the models as well as the time scopes adopted by different researchers.

As revealed by the extant literature, although a number of empirical studies on the relationship between crude oil price shocks and economic growth exist, most of such studies have largely focused on developed and developing MENA economies. Besides, there is yet no consensus among researchers and to the best of our knowledge, the few existing literature for SSA often employ time series analysis with smattering panel studies available. Given that the heterogeneity of results observed in the extant literature may be accounted for by the different methodologies employed by various authors (Lebdioui, 2021), this paper is, thus, imperative to fill this gap as it adopts the novel panel vector autoregression (PVAR) modelling framework for a sample of 32 SSA countries comprising 10 net oil exporters and 22 net oil importers. Furthermore, although several studies have employed the ARDL, VAR, SVAR, and PVAR models in their analysis, they have employed classical cointegration techniques which do not allow for an adequate number of lags for the VAR model. The use of the Toda-Yamamoto causality (1995) technique and the PMG-ARDL approach in this study, therefore, ensures the reliability of the estimated coefficients since it incorporates an adequate number of lags for the variables in the estimated model. 


\section{Methodological strategy}

\section{Model specification}

Cognisant of the objective of this study, which is to examine whether there exist a long-run and dynamic causal nexus between crude oil price and economic growth in SSA, it is necessary to specify the operational basis through which this can be attained. Given that most SSA countries rely on the exploitation and exportation of natural resources, it is believed that changes in the prices of various traded commodities (notably crude oil) can engender significant macroeconomic impacts. For example, oil exploitation can provide employment to the population, attract foreign direct investments (FDI) which in turn can enhance infrastructural development. Moreover, infrastructural investments in education and health may further enhance labour productivity, which is a key determinant of economic growth, as advocated by proponents of the endogenous growth theory (Solow 1956; Lucas 1988; Romer 1990). Equally, oil exploration activities are likely to engender environmental challenges through the emission of greenhouse gases like carbon dioxide (CO2). Thus, crude oil exploitation could be environment unfriendly, thereby limiting the possibilities of simultaneously achieving sustainable growth without compromising environmental quality. On the basis of the foregoing arguments, we derive the following theoretical model linking crude oil price (COP) and economic growth.

$$
\text { economic growth }=f(\text { crude oil price }, Y),
$$

where $Y$ is a vector of control variables likely to influence economic growth besides the variable of interest (that is, crude oil price). In line with the specified theoretical model, and following Kim and Loungani (1992) and Mankiw et al. (1992), the following econometric model is specified.

$$
\mathrm{GDP}_{\mathrm{it}}=\chi_{0}+\chi_{1} \mathrm{COP}_{i t}+\chi_{2} \mathrm{CO} 2_{i t}+\chi_{3} \mathrm{FDI}_{i t}+\chi_{4} \mathrm{POP}_{i t}+\varepsilon_{i t},
$$

where $\chi_{0}$ is the intercept; $\chi_{1}, \chi_{2}, \chi_{3}$ and $\chi_{4}$ are respective slope parameters of various explanatory variables (COP, CO2, FDI and POP); and $\varepsilon_{\mathbf{i t}}$ is the random error term in country $i$ and period $t$, assumed to be stationary. The various modelled variables are defined in the following section.

\section{Data and properties of variables}

This study uses annual panel data for 32 SSA countries over the period 1980-2017. The data was collected from the World Development Indicators of the World Bank Data Base (WDI 2019) and the US British Petroleum Statistical Review of World Energy (BP 2019). For the purpose of comparisons, we further split the sample into two sub-groups notably, ten net oil exporters and 22 net oil importers. ${ }^{1}$ However,

\footnotetext{
1 The 10 net oil exporters are: Angola, Cameroon, Congo-Brazzaville, Cote d'Ivoire, DR Congo, Equatorial Guinea, Gabon, Mauritania, Nigeria, and Sudan. The 22 net oil importers are: Benin, Bostwana, Bukina Faso, Burundi, Central African Republic, Chad, Gambia, Ghana, Kenya, Madagascar, Mali,
} 
the time frame and countries included in the sample was chosen based on the availability of relevant data. The dependent variable used is real GDP per capita (denoted GDP, measured in millions of current US dollars), explained principally by crude oil price (henceforth denoted COP, which is Brent crude price in current US dollars per barrel of oil). Other explanatory variables include carbon dioxide emissions (denoted $\mathrm{CO} 2$, measured in kilotons of $\mathrm{CO} 2$ ), population size (henceforth denoted POP, in annual percentages) and foreign direct investment (denoted FDI, measured by net inflows as a percentage of GDP). All variables are considered in natural logarithms, except FDI and POP. Moreover, the perceived correlations between the explanatory variables and the dependent variable are highlighted in Fig. 2.

A keen look at the line of best fit in Fig. 2a shows that oil price changes positively impact on the real GDP of SSA countries, implying that the real GDP of SSA counties decreases and increases with respective decreases and increases in crude oil price. Equally, Fig. 2b shows a positive link between real GDP and carbon dioxide emissions $\left(\mathrm{CO}_{2}\right)$, implying that as real GDP grows, environmental quality falls as more $\mathrm{CO} 2$ emissions are released. A similar relation is obtained for the nexus between real GDP and foreign direct investment as seen on Fig. 2c. However, Fig. 2d shows that there exist a negative relation between real GDP and population growth, implying that increases and decreases in population growth lead to respective reductions and increases in the real GDP of SSA countries. Thus, from the previewed scatter plots, it is expected that respective increases and decreases in crude oil price, FDI, and $\mathrm{CO}_{2}$ emissions will positively and negatively impact on the real GDP of SSA countries unlike increases in population growth which are expected to impact negatively on real GDP.

\section{Toda-Yamamoto causality procedure and PVAR modelling}

To examine the causality relation between the modelled variables, we employ the Toda and Yamamoto (1995) test which requires four main steps. First, we determine the maximum order of integration $(m)$ between variables. Second, the optimal lag order $(k)$ of the VAR model is determined. Third, the specified VAR model is estimated and lastly, the significance of the VAR model is tested with the help of a modified Wald statistic. Hence, the estimation of an augmented VAR $(k+m)$ model ensures the asymptotic $\chi^{2}$ distribution of the Wald statistic (Emirmahmutoglu and Kose 2011; Ayad and Belmokaddem 2017).

Moreover, the study adopts the PVAR estimation technique according to Abrigo and Love (2016) PVAR estimation technique according to Abrigo and Love (2016), which is an extension of the initial works of Love and Zicchino (2006). The PVAR model is adopted due to its ability to: (i) capture both static and dynamic interdependencies, (ii) treat the links across countries without restrictions, (iii) easily incorporate time variations in the coefficients and variance of the shocks, and (iv) account for cross sectional dynamic heterogeneities.

Footnote 1 (continued)

Mozambique, Niger, Rwanda, Senegal, Seychelles, Sierra Leone, South Africa, Togo, Uganda, Zambia, and Zimbabwe. 


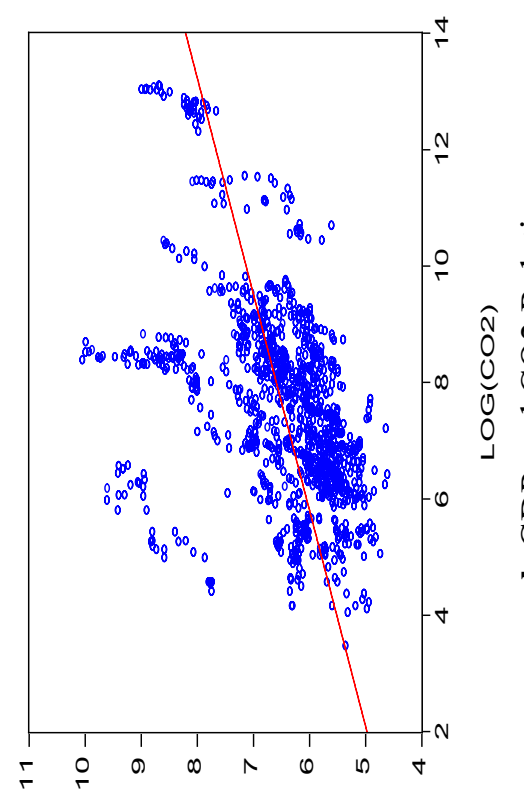

(d09y)907

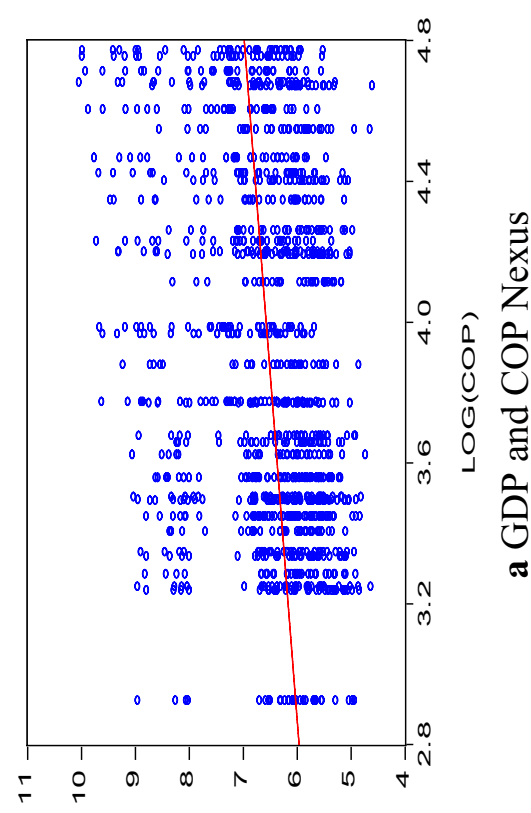

(d09y)901

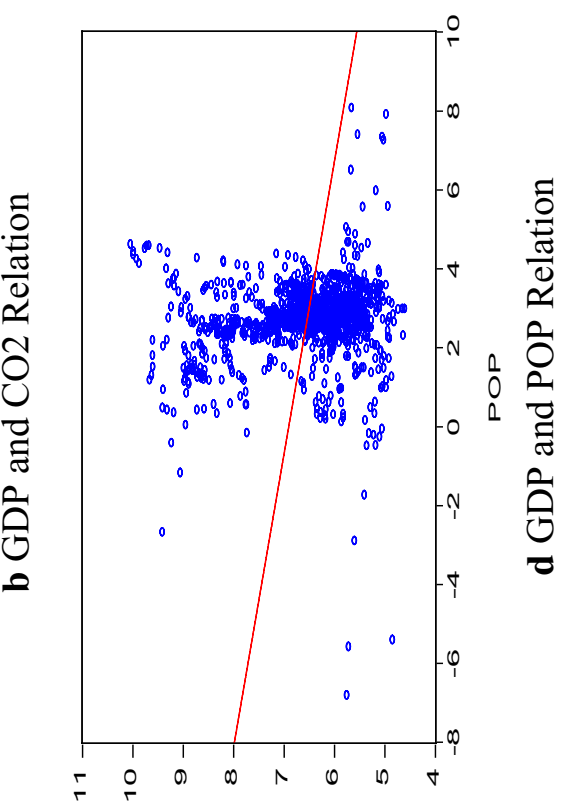

(dogy) 901

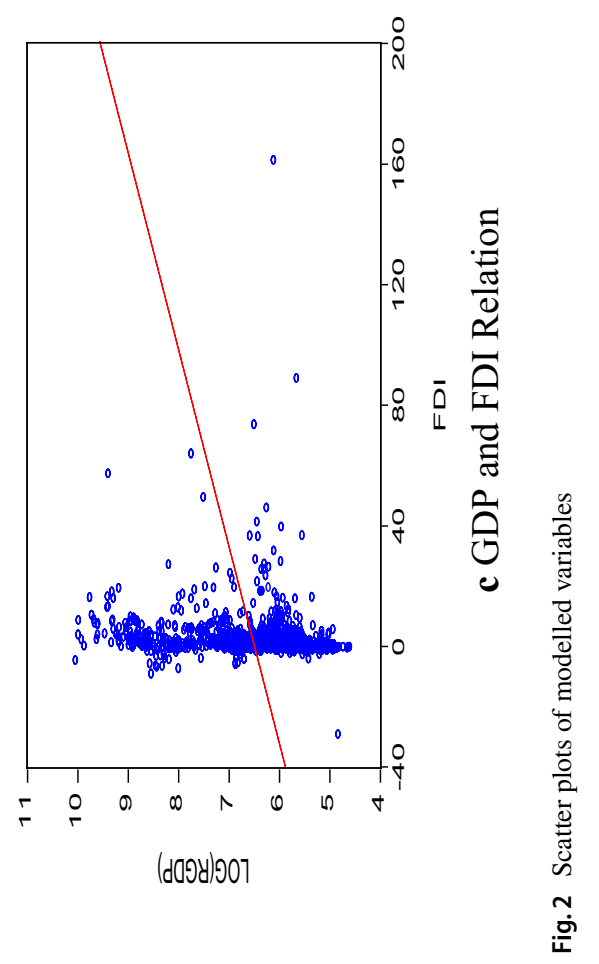

SN Business \& Economics

A SPRINGER NATURE journal. 
Consequently, consistent with earlier studies (Mallick and Mohsin 2007; Aziz and Dahalan 2015), the following PVAR model is specified.

$$
X_{i t}=\omega_{i}+\varphi_{i} X_{i t-i}+\varepsilon_{i t},
$$

where: $X_{i t}$ is an $(n \times 1)$ vector of endogenous variables (as specified in Eq. 2); $\varphi_{i}$ are $(n \times n)$ matrices of slope coefficients; $\omega_{i}$ is an $(n \times 1)$ vector of intercepts; $\varepsilon_{i t}$ is an $(n \times 1)$ vector of random errors; $i=1, \ldots$, Nandt $=1, \ldots, T$.

Consequently, based on our variables of interest, we specify the following pentavariate PVAR model in line with the Toda-Yamamoto procedure highlighted supra.

$$
\begin{aligned}
\mathrm{GDP}_{i t}= & \omega_{1 i}+\sum_{j=1}^{k+m} \alpha_{1 i j} \mathrm{GDP}_{i t-j}+\sum_{j=1}^{k+m} \beta_{1 i j} \mathrm{COP}_{i t-j}+\sum_{j=1}^{k+m} \gamma_{1 i j} \mathrm{CO}_{i t-j}+\sum_{j=1}^{k+m} \mu_{1 i j} \mathrm{FDI}_{i t-j} \\
& +\sum_{j=1}^{k+m} \pi_{1 i j} \mathrm{POP}_{i t-j} \\
\mathrm{COP}_{i t}= & \omega_{2 i}+\sum_{j=1}^{k+m} \beta_{2 i j} \mathrm{COP}_{i t-j}+\sum_{j=1}^{k+m} \alpha_{2 i j} \mathrm{GDP}_{i t-j}+\sum_{j=1}^{k+m} \gamma_{2 i j} \mathrm{CO}_{i t-j}+\sum_{j=1}^{k+m} \mu_{2 i j} \mathrm{FDI}_{i t-j} \\
& +\sum_{j=1}^{k+m} \pi_{2 i j} \mathrm{POP}_{i t-j}+\varepsilon_{2 i t}, \\
\mathrm{CO}_{i t}= & \omega_{3 i}+\sum_{j=1}^{k+m} \gamma_{3 i j} \mathrm{CO}_{i t-j}+\sum_{j=1}^{k+m} \alpha_{3 i j} \mathrm{GDP}_{i t-j}+\sum_{j=1}^{k+m} \beta_{3 i j} \mathrm{COP}_{i t-j}+\sum_{j=1}^{k+m} \mu_{3 i j} \mathrm{FDI}_{i t-j} \\
& +\sum_{j=1}^{k+m} \pi_{3 i j} \mathrm{POP}_{i t-j}+\varepsilon_{3 i t}, \\
& +\sum_{j=1}^{k+m} \gamma_{4 i j} \mathrm{CO}_{i t-j}+\sum_{j=1}^{k+m} \pi_{4 i j} \mathrm{POP}_{i t-j}+\sum_{j=1}^{k+m} \pi_{4 i j} \mathrm{POP}_{i t-j}+\varepsilon_{4 i t} \\
\mathrm{FDI}_{i t}= & \omega_{4 i}+\sum_{j=1}^{k+m} \mu_{4 i j} \mathrm{FDI}_{i t-j}+\sum_{j=1}^{k+m} \alpha_{4 i j} \mathrm{GDP}_{i t-j}+\sum_{j=1}^{k+m} \beta_{4 i j} \mathrm{COP}_{i t-j} \mathrm{CO}_{i t-j}^{+} \sum_{j=1}^{k+m} \mu_{5 i j} \mathrm{FDI}_{i t-j}+\varepsilon_{5 i t} \cdot \\
k+m & \sum_{5 i j} \mathrm{POP}_{i t-j}+\sum_{j=1} \alpha_{5 i j} \mathrm{GDP}_{i t-j}+\beta_{5 i j} \mathrm{COP}_{i t-j}
\end{aligned}
$$


Table 1 Synopses of descriptive statistics and correlations

\begin{tabular}{lcccrr}
\hline & \multicolumn{1}{l}{ GDP } & COP & \multicolumn{1}{l}{ CO2 } & \multicolumn{1}{l}{ FDI } & \multicolumn{1}{l}{ POP } \\
\hline Mean & 1426.878 & 58.56209 & $18,179.24$ & 2.712159 & 2.723678 \\
Maximum & $22,942.58$ & 118.7083 & $503,112.4$ & 57.83755 & 8.117928 \\
Minimum & 100.0303 & 18.72299 & 66.006 & -28.62426 & -6.766223 \\
Std. Dev & 2605.472 & 31.34794 & $69,924.4$ & 5.300988 & 0.981735 \\
GDP & 1.0000 & & & & \\
COP & 0.2791 & 1.0000 & & & \\
CO2 & 0.4334 & 0.1273 & 1.0000 & & \\
FDI & 0.1239 & 0.0629 & -0.0969 & 1.0000 & 1.0000 \\
POP & -0.1019 & 0.0336 & -0.0428 & 0.0678 & \\
\hline
\end{tabular}

Std. Dev. denotes standard deviation

where $k$ is the optimal lag length; $m$ is the maximal order of integration of the variables in the system; $\alpha, \beta, \gamma, \mu$, and $\pi$ are $(5 \times 5)$ matrices of slope coefficients.

\section{Empirical results and discussion}

This section begins with the presentation of preliminary results, notably with regard to correlation analysis, unit root and causality tests, before discussing the baseline empirical results of the PVAR model.

\section{Descriptive Statistics and correlation analysis}

A brief statistical description and correlation analysis of the modelled variables is shown in Table 1. The historical background provided by the descriptive statistics shows significant variations over the study period. However, as evidenced by the mean and standard deviation values, the level of variability is moderate for some variables (COP, FDI and POP) and somewhat volatile for others (GDP and $\mathrm{CO}_{2}$ emissions). Real GDP has reached maximum and minimum values of $\$ 22,942.58$ and $\$ 100.0303$, respectively. This maximum value was recorded by Equatorial Guinea in 2008 while the minimum was recorded by Uganda in 1980 . Also, $\mathrm{CO}_{2}$ emissions have reached respective maximum and minimum values of 503,112.4 and 66.01 kilotons recorded by South Africa in 2009 and Equatorial Guinea in 1985. This indicates that although the rate of $\mathrm{CO}_{2}$ emissions has risen since the mid1980s, it has as well witnessed a downward trend across SSA since its peak value in 2009. Equally, we notice that Equatorial Guinea with the highest record value of GDP is the same country with the lowest record value of $\mathrm{CO}_{2}$ emissions. This therefore leaves us with the belief that economic growth is environment-friendly.

Moreover, the correlation results show evidence of the existence of a generally weak correlation between modelled variables. However, while there is weak positive correlation between GDP and COP, CO2 and FDI, the correlation is negative 
between GDP and population growth. Thus, this weak correlation between modelled variables shows evidence of the absence of multicolinearity which is indicative of a strong explanatory power of the estimated coefficients of our model.

\section{Panel unit root tests}

Panel unit root tests were conducted to determine the order of integration of the modelled variables. Accordingly, we employed two conventional panel unit root tests notably Levin, Lin and Chu (LLC) and Im, Pesaran and Shin (IPS). Even though both the LLC and the IPS tests employ the null hypothesis that there is a unit root, the LLC test, developed by Levin et al. (2002) is based on the null hypothesis that there is a common unit root process across cross sections while the IPS test, developed by Im et al. (2003) assumes an individual unit root process across cross sections. Table 2 presents the LLC and IPS unit root results at levels (denoted I(0)) and first difference (denoted $\mathrm{I}(0)$ ).

The panel unit root results reveal that the variables are not all stationary at levels. Specifically, both the LLC and IPS results show that while FDI and POP are stationary at levels; all other variables notably $\mathrm{CO}_{2}$, COP and GDP become stationary at the first difference. Equally, we observe that the stationarity of all the variables is justified at the $1 \%$ level of significance. The presence of I(1) variables in the series is indicative of the presence of cointegration among variables. Hence, the need to carry out cointegration analysis. Moreover, based on the Toda-Yamamoto (1995) cointegration procedure, the $\mathrm{I}(0)$ and $\mathrm{I}(1)$ nature of the variables implies that the maximal order of integration to be adopted in the model is one (i.e. $m=1$ ). Moreover, in accordance with the modelling procedure developed supra, the optimal lag length was determined. We retain an optimal lag length of three (i.e. $k=3$, see Table 3) as selected by the Schwarz information criterion (SC) and Hannan-Quinn information criterion (HQ).

\section{Causality analysis}

Having established that the variables are both $\mathrm{I}(0)$ and $\mathrm{I}(1)$, we proceed to verify whether or not the modelled variables are actually cointegrated. Consequently, we employed the Toda-Yamamoto (1995) causality test. The causality results in Table 4 show evidence of the existence of both unidirectional and bidirectional causality among variables. For example, we observe bidirectional causality between crude oil price and real GDP. Specifically, there is evidence at the $1 \%$ significance level that long-run changes in crude oil price can be explained by changes in GDP and vice versa, thereby indicating a feedback effect. We also find bidirectional causality between FDI and CO2. Besides these two cases in which a feedback effect is observed, all other variables exhibit unidirectional causality. 


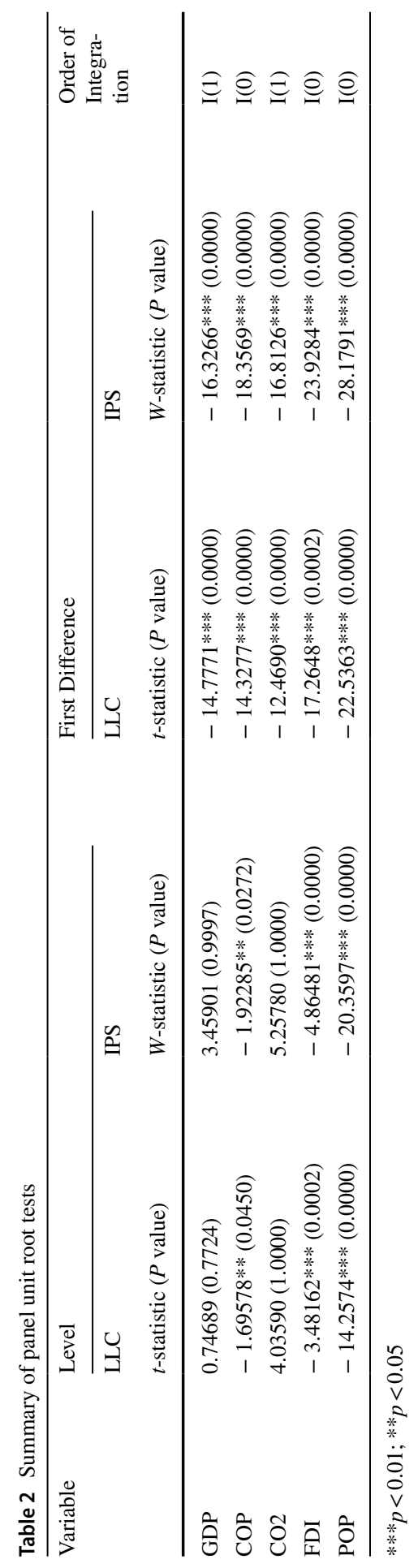

SN Business \& Economics 
Table 3 Lag length selection

\begin{tabular}{llllll}
\hline Lag & LR & FPE & AIC & SC & HQ \\
\hline 1 & NA & 0.000877 & 7.149839 & 7.273917 & 7.197029 \\
2 & 168.1035 & 0.000776 & 7.028311 & 7.276468 & 7.122693 \\
3 & 253.4070 & 0.000629 & 6.818046 & $7.190282^{*}$ & $6.959618^{*}$ \\
4 & $77.90889^{*}$ & $0.000610^{*}$ & $6.788105^{*}$ & 7.284419 & 6.976868 \\
\hline
\end{tabular}

FPE Final prediction error; $L R$ sequential modified LR test statistic; $A I C$ Akaike information criterion

*Indicates lag order selected by the criterion

\section{Baseline PVAR results}

After ensuring an appropriate lag length $(\mathrm{k}+\mathrm{m})$ for the panel VAR model, following the Toda-Yamamoto (1995) procedure, we conducted impulse response analysis for the panel of 32 Sub-Saharan Africa (SSA) countries. Empirical evidence from the impulse response functions (IRFs) in Fig. $3^{2}$ indicates that real GDP positively responds to forecast errors that occur in crude oil price. This implies that crude oil price leads to an increase in economic growth in SSA. This effect is consistent both in the short- and long-run periods. Equally, foreign direct investment (FDI) and population growth (POP) positively contribute to real GDP both in the short-run and long-run periods. Nevertheless, we observe both a positive and negative response of real GDP to $\mathrm{CO}_{2}$ emissions. Specifically, while there is a positive effect of $\mathrm{CO}_{2}$ emissions on real GDP in the short run (between periods 1 and period 9), the effect is negative in the long-run (between periods 10 and period 20).

Based on the foregoing results, and given that most SSA countries depend on natural resources for foreign exchange earnings, we assert that crude oil price hikes are growth enhancing in SSA. This positive effect of crude oil price on the economic growth of SSA economies contradicts the findings of Aziz and Dahalan (2015) and Omolade et al. (2019) but consonant to the findings of Deaton (1999) who opined that oil price hikes have positive effects on Africa's economic development. The results further reveal that crude oil price is environment unfriendly as depicted by the positive response of $\mathrm{CO} 2$ emissions to crude oil price shocks (see appendix 1).

Notwithstanding, given that the study incorporates both net oil importers and exporters, we further split the sample into two sub-groups and estimate IRFs for both sub-groups. This is to verify whether the relationship obtained between GDP growth and crude oil price is consistent with existing studies if the countries are considered separately as net oil exporters and net oil importers. From the comparative analysis of the IRFs in Figs. 4 and 5 we observe that there are some disparities in the theoretical expectations regarding the effect of oil prices on the economic growth of net oil exporters and net oil importers.

Results from Fig. 4 show that the effect of crude oil price on real GDP is asymmetric for net oil exporters. Specifically, while the effect is positive in the short run,

\footnotetext{
${ }^{2}$ Figure 3 presents only the partial PVAR results limited to the response of real GDP to shocks in various endogenous variables. Thus, while Fig. 3 presents results for the GDP model, the complete results of the pentavariate PVAR model are presented in appendix 1.
} 


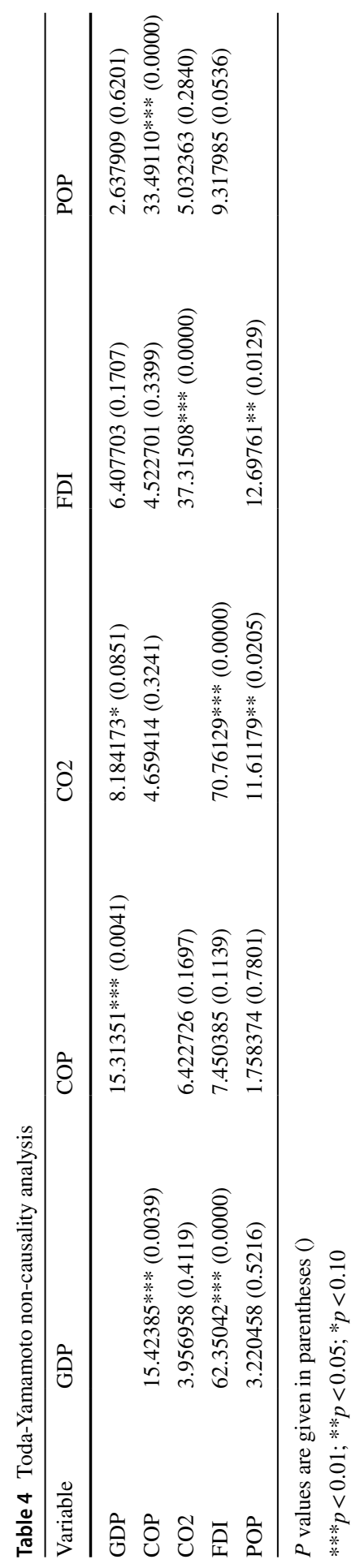



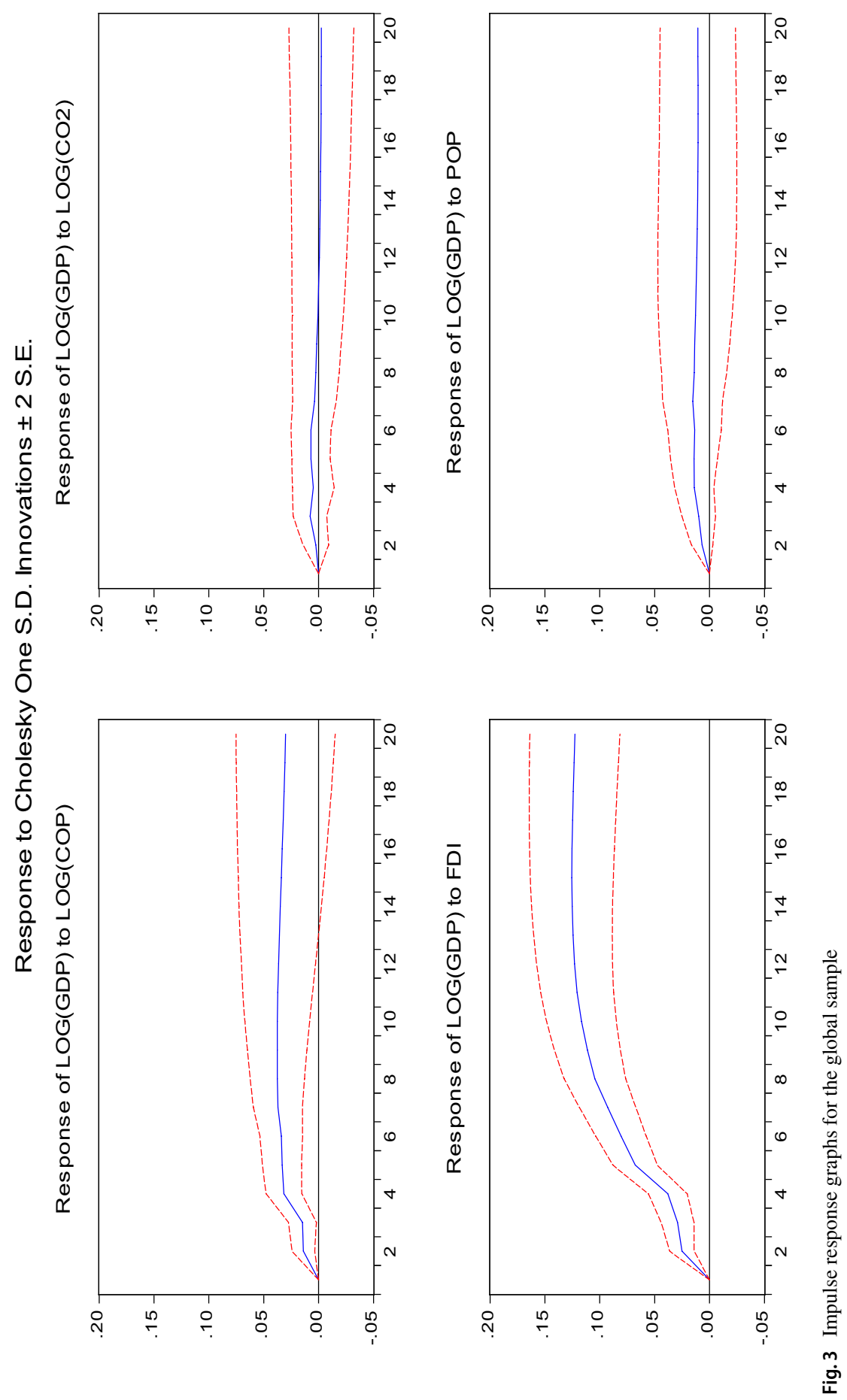

SN Business \& Economics 

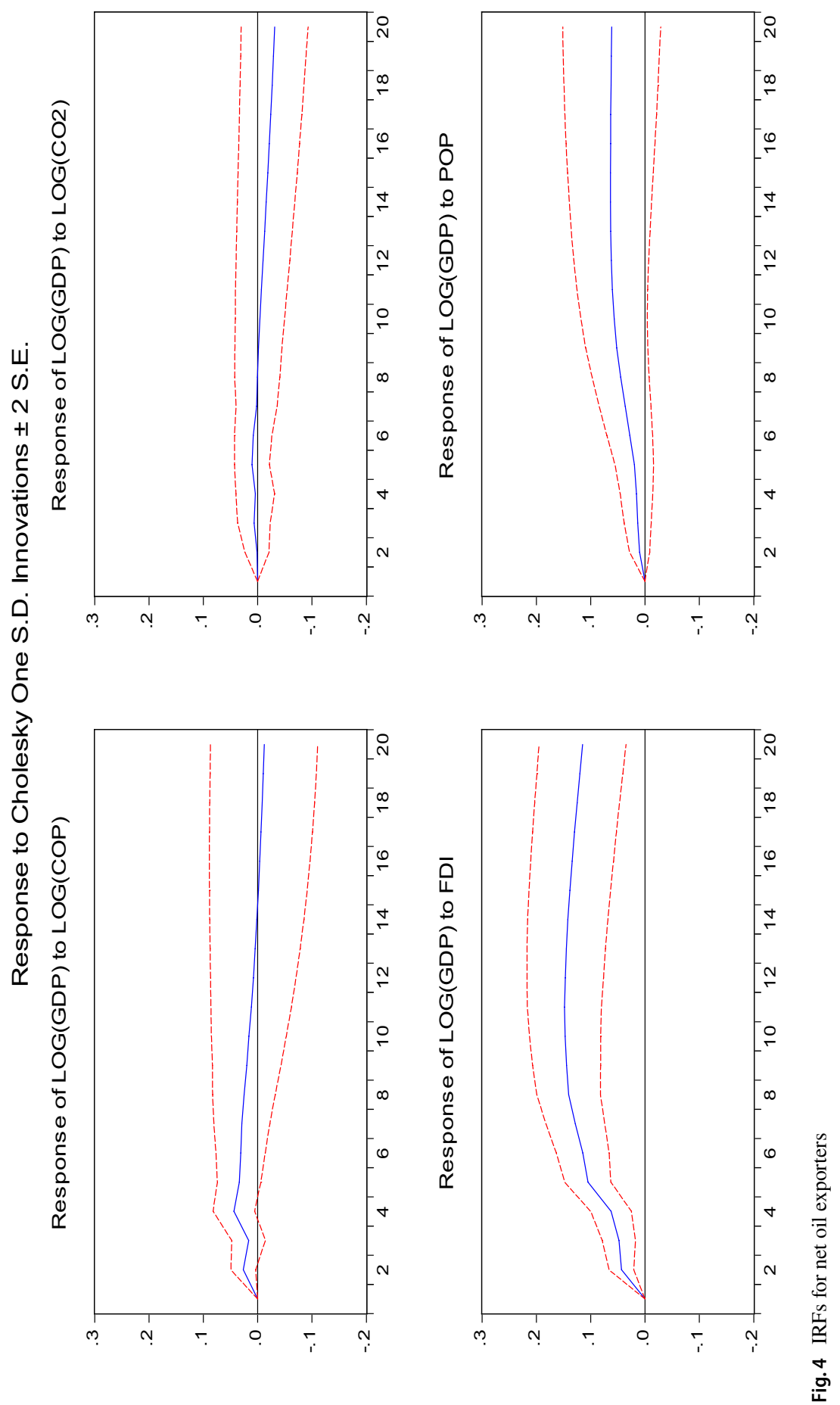

SN Business \& Economics 

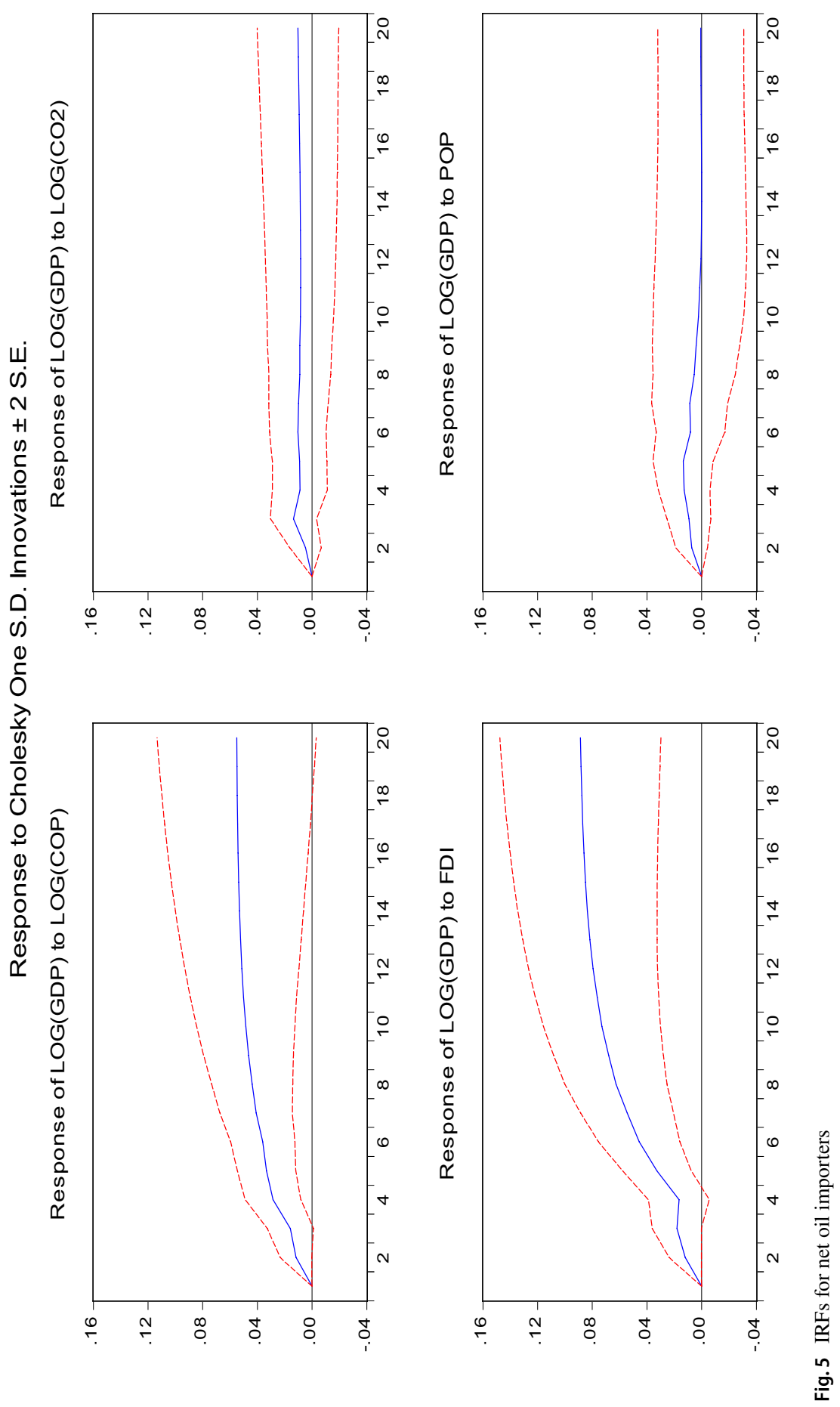

SN Business \& Economics 
it is negative in the long run. Hence, this confirms results of earlier studies (Akanni 2007; Besso and Pamen 2017; Ftiti et al. 2016; Omojolaibi and Egwaikhide 2013) which is indicative that oil rich countries suffer from the resource curse. This negative long-run effect may be explained by the high levels of corruption (Bulte and Damania 2008; Leite and Weidmann 1999; Zalle, 2019), economic mismanagement and embezzlement of oil windfalls (Badeeb et al., 2017) and poor institutional quality (Sachs and Warner 1995; Sala-i-Martin and Subramanian 2013) that are predominant in natural resource-rich economies especially Sub-Saharan Africa.

Withal, Fig. 5 reveals that the real GDP of net oil importers responds positively to crude oil price both in the short-run and long-run periods. However, this positive relation for net oil importers is contrary to the findings of Nkoto (2006) who concludes that Southern African net oil importers like South Africa are more vulnerable to oil price shocks than their net oil-exporting counterparts. Nevertheless, it may be unsurprising that resource-poor countries do avoid the resource curse since these countries may be more cautious in the management of the few resources at their disposal. Moreover, the economies of resource-poor countries are likely to be more diversified than those of their resource-rich counterparts.

\section{Robustness checks}

According to Abrigo and Love (2016), it is important to conduct robustness checks on the PVAR model since the results could be sensitive to the number of lags. Consequently, we verified for stability by examining the autoregressive (AR) roots table and graph. Thus, the roots of the AR characteristic polynomial (see appendix 2) indicate that the specified model is stable given that the modulus of all the roots is less than one. This is further confirmed by the unit circle (see appendix 3) which is evidenced by the fact that no root lies outside the unit circle. The results are consistent with the postulations of Abrigo and Love (2016) and Lutkepohl (2005). The validation of the stability condition of the estimated PVAR model is indicative that the results of the IRFs can be used for policy recommendations.

In addition, we further verified the pertinence and robustness of the PVAR results by employing the conventional panel ARDL approach propounded by Pesaran et al. (1999) considered to be suitable for I(0) and I(1) series. The panel ARDL model is estimated with an automatically selected optimal lag length, $\operatorname{ARDL}(1,1,1,1,1)$ following the Schwarz information criterion (SC). Indeed, the panel ARDL results (see appendix 4) largely remain consistent with the baseline PVAR results. Likewise, the existence of long-run causality among modelled variables is further confirmed by the significantly negative coefficient of the error correction term (ECT-1) at the $1 \%$ level of significance. Equally, the robustness of the panel ARDL results was verified with the help of diagnostic tests. Specifically, we conducted the panel unit root test on the estimated PMG/ARDL residuals as recommended by Pesaran (2007). Accordingly, results of the residual unit root tests exhibit significance at $1 \%$ (see appendix 5) indicating that the residual series is stationary at levels, thereby confirming the stability of the panel ARDL model. 


\section{Conclusion and policy implications}

This paper revisits the resource curse hypothesis by employing the PVAR estimation technique to examine the nexus between crude oil price and economic growth in 32 Sub-Saharan African countries over the period 1980-2017. We also employed the Toda-Yamamato (1995) causality test to investigate the causal relationship between modelled variables. Results of the IRFs of the PVAR model show a positive significant relation between crude oil price and economic growth both in the short- and long-run. However, varying results are found when the sample of 32 SSA countries is split into net oil importers and exporters. First, in the case of net oil exporters, while the effect of crude oil price on economic growth is positive in the short run, it is negative in the long run, indicating evidence of the resource curse. Second, we find a positive nexus between crude oil price and economic growth in the case of net oil importers. This effect is consistent both in the short and long run.

Nevertheless, prior to the PVAR estimations, a number of tests were conducted. First, we showed that the modelled variables were stationary at levels $\mathrm{I}(0)$ and at first difference I(1) with the help of two conventional panel unit root tests notably (Levin et al. 2002; Im et al. 2003) . Then, we found evidence of bidirectional causality between real GDP and crude oil price. Specifically, there is evidence at the $1 \%$ significance level that long-run changes in crude oil price can be explained by changes in GDP and vice versa, thereby indicating a feedback effect. A feedback effect is also observed between FDI and $\mathrm{CO} 2$. Besides these two cases in which a feedback effect is observed, other variables exhibit unidirectional causality.

Consequently, to boost economic growth in SSA, it is imperative for various governments to efficiently manage oil windfalls and increase investments in human capital in view of enhancing the development of the oil sector. Moreover, SSA countries can avoid the resource curse by intensifying strategies aimed at curbing corruption as well as diversifying their economies through a careful identification and development of other economically beneficial sectors.

Supplementary Information The online version contains supplementary material available at https://doi. org/10.1007/s43546-021-00179-x.

Funding No funding was received for this study.

Availability of data and materials The datasets used to analyse the underlying relationships in this study were collected from: World Development Indicators of the World Bank (2019): https://datacatalogue. worldbank.org>dataset, British Petroleum Statistical Review of World Energy (2019): http://www.bp. $\mathrm{com} /$ statisticalreview.

Code availability Not applicable.

\section{Declarations}

Conflict of interest There is no conflict of interests. 


\section{References}

Abrigo MRM, Love I (2016) Estimation of panel vector autoregression in Stata. Stata J 16(3):778-804

Achuo ED, Dinga GD, Njuh CJ, Ndam NL (2020) The socioeconomic impacts of the COVID-19 pandemic in Africa. Int J Progres Sci Technol 22(2):1-10

Akanni OP (2007) Oil wealth and economic growth in oil exporting African countries. African Economic Research Consortium, AERC Research Paper 170

Auty RM (1993) Sustaining development in mineral economies: The resource curse thesis. Routledge, London. https://doi.org/10.4324/9780203422595/

Auty RM (2001) The political economy of resource-driven growth. Eur Econ Rev 45(4-6):839-846

Ayad H, Belmokaddem M (2017) Financial development, trade openness and economic growth in MENA countries: TYDL panel causality approach. Theor Appl Econ 24(1):233-246

Aziz MIA, Dahalan J (2015) Oil price shocks and macroeconomic activities in Asean-5 countries: a panel VAR approach. Eurasian J Bus Econ 8(16):101-120

Badeeb RA, Lean HH, Clark J (2017) The evolution of the natural resource curse thesis: a critical literature survey. Resour Policy 51:123-134

EXIM Bank (2018) Oil price and international trade in petroleum crude and products: An Indian perspective. Export-Import Bank of India, Working Paper No.70

Berument MH, Ceylan NB, Dogan N (2010) The impact of oil price shocks on the economic growth of selected MENA countries. Energy J 31(1):149-176

Besso CR, Pamen EP (2017) Oil price shock and economic growth: experience of CEMAC countries. Theor Pract Res Econ Fields 8(1):5-18

BP (2019) British Petroleum Statistical Review of World Energy June 2019. Available via DIALOG. http://www.bp.com/statisticalreview. Accessed 29 April 2020

Bulte E, Damania R (2008) Resources for sale: corruption, democracy and the natural resource curse. BE J Econ Anal Poli. https://doi.org/10.2202/1935-1682.1890

Carmignani F, Avom D (2010) The social development effect of primary commodity export dependence. Ecol Econ 10(2):317-330

Chen D, Chen J, Härdle WK (2015) The influence of oil price shocks on China's macroeconomy: a perspective of international trade. J Gov Regul 4(1):178-189

Deaton A (1999) Commodity prices and growth in Africa. J Econ Perspect 13(3):23-40

Emirmahmutoglu F, Kose N (2011) Testing for Granger causality in heterogeneous mixed panels. Econ Model 28:870-876

Forgha NG, Sama MC, Achuo ED (2015) Petroleum products price fluctuations and economic growth in Cameroon. Growth 2(2):30-40

Ftiti Z, Guesmi K, Teulon F (2016) Relationship between crude oil prices and economic growth in selected OPEC countries. J Appl Bus Res 32(1):11-21

Hamilton J (1983) Oil and the macroeconomy since World War II. J Polit Econ 96:593-617

Herrera AM, Lagalo LG, Wada T (2015) Asymmetries in the response of economic activity to oil price increases and decreases. J Int Money Finance 50:108-133

Hooker C (1986) Effects of oil price and exchange rate variations on government revenue in China. J Econ 2(1):2-3

Im KS, Pesaran MH, Shin Y (2003) Testing for unit roots in heterogeneous panels. J Econom 115:53-74

IMF (2020) World economic outlook, April 2020: The Great Lockdown. International Monetary Fund, Washington, DC

Khan G, Kiani A, Ahmed AM (2017) Globalization, endogenous oil price shocks and Chinese economic activity. Lahore J Econ 22(2):39-64

Kim I, Loungani P (1992) The role of energy in real business cycle models. J Monet Econ 29(2):173-189

Kojima M, Matthews W, Sexsmith F (2010) Petroleum markets in Sub Saharan Africa: analysis and assessment of 12 countries. Extractive Industries for Development Series No.15

Kydland F, Prescott E (1982) Time to build and aggregate fluctuations. Econometrica 50(6):1345-1370

Lebdioui A (2021) The multidimensional indicator of extractives-based development (MINDEX): a new approach to measuring resource wealth and dependence. World Dev 147:105633. https://doi.org/10. 1016/j.worlddev.2021.105633

Lee KS, Ratti RA (1995) Oil shocks and the macro-economy: The role of price variability. Energy J 16(4):39-56 
Leite MC, Weidmann J (1999) Does mother nature corrupt? Natural resources, corruption, and economic growth. IMF Working Paper No 34; International Monetary Fund

Levin A, Lin CF, Chu C (2002) Unit root tests in panel data: asymptotic and finite-sample properties. J Econom 108:1-24

Love I, Zicchino L (2006) Financial development and dynamic investment behaviour: evidence from panel VAR. Q Rev Econ Finance 46(2):190-210

Lucas RE (1988) On the mechanics of economic development. J Monet Econ 22(1):3-42

Lutkepohl H (2005) New introduction to multiple time series analysis. Springer, New York

Mallick SK, Mohsin M (2007) On the effects of inflation shocks in a small open economy. Aust Econ Rev 40(3):253-266

Mankiw NG (1995) The growth of nations. Brook Pap Econ Act 26(1):275-326

Mankiw NG, Romer D, Weil DN (1992) A contribution to the empirics of economic growth. Q J Econ 107(2):407-437

Mark G, Olsen T, Mysen Y (1994) Impact of oil price variation on the growth prospects of African economies. Afr Econ Writ Publ 2(5):80-83

Mendoza O, Vera D (2010) The asymmetric effects of oil shocks on an oil-exporting economy. Cuadernos De Economía 47(135):3-13

Mesagan EP, Alimi OY, Adebiyi KA (2018) Population growth, energy use, crude oil price, and the Nigerian economy. Econ Stud 27(2):115-132

Miamo CW, Achuo ED (2021) Crude oil price and real gdp growth: an application of ARDL Bounds cointegration and Toda-Yamamoto causality tests. Econ Bull 41(3):1615-1626

Mukhtarov S, Aliyev S, Zeynalov J (2020) The effect of oil prices on macroeconomic variables: evidence from Azerbaijan. Int J Energy Econ Policy 10(1):72-80

Nchofoung TN, Achuo ED, Asongu SA (2021) Resource rents and inclusive human development in developing countries. Resour Policy 74(4):102382. https://doi.org/10.1016/j.resourpol.2021.102382

Nkoto JC (2006) The impact of higher oil prices on Southern African countries. J Energy South Africa 17(1):10-17

Ogboru I, Rivi MT, Idisi P (2017) The impact of changes in crude oil prices on economic growth in Nigeria: 1986-2015. J Econ Sustain Dev 8(12):78-89

Omojolaibi JA, Egwaikhide FO (2013) A panel analysis of oil price dynamics, fiscal stance and macroeconomic effects: the case of some selected African countries. Central Bank Nigeria Econ Financ Rev 51(1):61-91

Omolade A, Ngalawa H, Kutu A (2019) Crude oil price shocks and macroeconomic performance in Africa's oil-producing countries. Cogent Econ Finance 7(1):1607431

Oriakhi DE, Osaze ID (2013) Oil price volatility and its consequences on the growth of the Nigerian economy: an examination (1970-2010). Asian Econ Financ Rev 3(5):683-702

Pesaran MH (2007) A simple panel unit root test in the presence of cross-section dependence. J Appl Econ 22(2):265-312

Pesaran MH, Shin Y, Smith RJ (1999) Pooled mean group estimation and dynamic heterogeneous panels. J Am Stat Assoc 94:621-634

Qazi LT (2013) The effects of oil price shocks on economic growth of oil exporting countries: a case of six OPEC economies. Bus Econ Rev 5(1):65-87

Romer P (1990) Are nonconvexities important for understanding growth? NBER Working Paper No. 3271

Sachs JD, Warner AM (1995) Natural resource abundance and economic growth. NBER Working Paper No. 5398

Sachs JD, Warner AM (1997) Sources of slow growth in African economies. J Afr Econ 6(3):335-376

Sachs JD, Warner AM (2001) The curse of natural resources. Eur Econ Rev 45(4-6):827-838

Sala-i-Martin X, Subramanian A (2013) Addressing the natural resource curse: an illustration from Nigeria. J Afr Econ 22(4):570-615

Samimi AJ, Shahryar B (2009) Oil price shocks, output and inflation: evidence from some OPEC countries. Aust J Basic Appl Sci 3(3):2791-2800

Samuelson PA, Nordhaus WD (1985) Economics, 12th edn. McGraw-Hill Book Company, New York Samuelson PA, Nordhaus WD (2009) Economics, 12th edn. McGraw-Hill Book Company, New York Solow RM (1956) A contribution to the theory of economic growth. Q J Econ 70(1):65-94

Stadler GW (1994) Real business cycles. J Econ Lit 32(4):1750-1783

Steinbach R, Sandhu J (2020) Regional outlooks: Sub-Saharan Africa. Global economic prospects: slow growth, policy challenges. World Bank, Washington, DC, pp 141-175 
Toda HY, Yamamoto T (1995) Statistical inference in vector autoregressions with possibly integrated processes. J Econ 66:225-250

United Nations (2015) Transforming our world: the 2030 agenda for sustainable development. Available at: https://sustainabledevelopment.un.org/post2015/transformingourworld/publication

WDI (2019) World Development Indicators Data Catalogue. Available via DIALOG. https://datacatalogue.worldbank.org >dataset. Accessed 28 Jan 2019

Yoshino N, Taghizadeh-Hesary F (2014) Economic impacts of oil price fluctuations on developed and emerging economies. IEEJ Energy J 9(3):58-75

Zalle O (2019) Natural resources and economic growth in Africa: the role of institutional quality and human capital. Resour Policy 62:616-624 